\title{
MUNICIPAL BONDS AS THE FINANCING STRATEGY FOR URBAN INFRASTRUCTURE: CASE STUDY OF JAKARTA MRT ${ }^{1}$
}

\author{
Eko Nur Surachman \\ Head of Evaluation on Government Support, PPP Unit, Ministry of Finance \\ Gedung Frans Seda Lt. 1, Jl. Wahidin No. 1, Jakarta Pusat 10710 \\ Hadi Setiawan \\ Researcher at Fiscal Policy Agency, Ministry of Finance \\ Gedung RM Notohamiprodjo, Jl. Wahidin Raya No. 1, Jakarta Pusat 10710
}

\begin{abstract}
The construction of Jakarta MRT Phase I has been carried out by using funds from foreign debt. Meanwhile, Jakarta MRT Phase II or other local infrastructure projects are still waiting for new funding scheme. One alternative is municipal bonds. This study investigate the possibilities of using municipal bonds to finance urban infrastructure project with the case study of Jakarta MRT Phase I. The analyzed use three perspectives including financial aspect, legal aspect, and Jakarta financial capacity aspect. Financial analysis using discounted cash flow (DCF), net present value (NPV) and internal rate of return (IRR). Secondly, study literature is used in the legal analysis by exploring specific regulations regarding the municipal bonds. Finally, the Jakarta Regional Budget and Jakarta Budget Audit Report is examined to get insight and depth information regarding its financial capacity. The result is municipal bonds are feasible as the source of financing Jakarta MRT Project.
\end{abstract}

Keywords: Jakarta MRT Project; Municipal Bonds; Infrastructure financing.

JEL Classification: R42, H74, H76, G12

\section{INTRODUCTION}

The condition of traffic congestion in Jakarta today has been on an alarming level. Currently the average speed of vehicles in Jakarta is only about $16 \mathrm{~km} /$ hour. This condition causes a huge waste. Wastage is expected to reach approximately Rp65

\section{Korespondensi dengan Penulis:}

Hadi Setiawan, Tlp. 021-3840151; Fax. 021-3842542

e-mail: hadi.setia@gmail.com

1 This article is an enhancement of a paper presented on 9th International Conference of BEMP 2015 entitled "Municipal Bond As A Financing Strategy For Investment On Urban Infrastructure: A Study Case of MRT Jakarta" presented by the authors 


\section{Jurnal Keuangan dan Perbankan | KEUANGAN}

Vol. 20, No.3, September 2016: 369-381

trillion/year by 2020. This number is 5 times compared to the estimated losses due to congestion that occurred in 2005 amount Rp12.8 trillion/year (Perdana, 2013). Ali, in Jakarta Transportation Council ${ }^{2}$, also mentions that the losses due to congestion in Jakarta reached Rp28,1 trillion/year consisting of losses due to wastage of fuel amount Rp10,7 trillion/year, less productive time of road users are expected Rp9,7 trillion/year, and losses due to road pollution of Rp5,8 trillion/year. All the numbers above indicate a huge losses that would be more useful if used for another beneficial expense such as infrastructure development, poverty alleviation, job creation, or helping the fund for climate change programs.

This congestion is caused by a large number of vehicles. Data in 2013 showed that the number of vehicles in Jakarta has reached 16.01 million units, which consist of 4.10 million unit cars and 11.91 million units of motorcycle. This number is increasing every year with an average growth of 11\%/year (BPS Jakarta, 2014). This phenomenon is the result of economy growth in Indonesian and the fast growing number of middle-income groups in Indonesia.

Unfortunately, this economic growth and the increase of middle class population are not accompanied by the appropriate growth in the availability of infrastructure including roads and public transport. Today, the total length of road in Jakarta is only about $4 \%$, while ideally is around $10 \%-15 \%$. This condition getting worse by the ratio of private vehicles compared to public transport which is only $98 \%$ versus $2 \%$. The numbers of private vehicles only carry $49.7 \%$ movement of people per day, while public transport had to move people of $50.3 \%$ per day (Koalisi TDM, n.d.).

The Government of Indonesia (GOI) has realized the need for developing and implementing a more comprehensive and integrated public transport development for DKI Jakarta and the Jabotabek region since the early eighties. One of the solutions made by DKI Jakarta is constructing the MRT project. Finally, after much deliberation, the development the project began by the end of 2013.

This project will have several major impacts, including increase capacity of public transportation, reduction of travel time, employment creation, environmental impact (an estimated 93,663 tons of $\mathrm{CO} 2$ per year, or 0.7 percent of total $\mathrm{CO} 2$ emissions before Jakarta MRT implementation will be reduced), and other intangible impacts, such as reduced number of traffic accidents and traffic jam (JBIC Saprof Study Team, 2005).

In term of financing, the project is still depend on foreign loans, which is Japan loans with the portion of $49 \%$ as the central government loans (grants to government of DKI Jakarta) and the remaining $51 \%$ become responsibility of government of DKI Jakarta as the subsidiary loan.

Actually, besides loans, infrastructure financing can also use other sources, which one of it is bonds i.e muncipal bonds (Gardner \& Wright, 2011). With municipal bond, Regional Government will create local financial independence, filling the financing gap area, and engaging the community's role in regional development (Sheikh \& Asher, 2012). Furthermore, with municipal bonds, government can further accelerate the process of regional development without rely on central government funding.

However, municipal bond must be able to provide good yields so that it can be sold on the market (Damodaran, 2011). In order to simulate and run the scenario of bond issuance to finance the project, IRR number is the same meaning with bond yields (Sigman, 2005). It means that IRR

http://dtk-jakarta.or.id/v3/en/berita/wow-kerugian-kemacetan-di-jakarta-capai-rp-28-t-per-tahun/ 
should be at least the same with the risk-free 30 years government bond yield to the make the investor interesting enough to buy the bond. In addition, in order to be published, municipal bond must also meet all the requirements of the existing regulations. The capacity of the issuer is one of the investor's considerations when buying a bond. This is reflected in the rating valuation of credit rating agencies which states that an issuer classified as investment grade entity or not.

Therefore, this study tries to investigate the possibilities of using municipal bond to finance the regional infrastructure project, with the case study of MRT Phase I. The uniqueness of this study resides on 2 areas, which are (i) exploring the chance of regional government to build the infrastructure on their own resources and (ii) examining the financial perspective of the project to be financed by bond and the response of financial market to the proposed municipal bond.

\section{LITERATURE REVIEW}

\section{Definition and Types of Municipal Bond}

Municipal bond represent a promise by a state or local government as the issuers to repay to lenders as the investors an amount of money borrowed (called principle) along with interset according to a fixed schedule (O'Hara, 2012). While U.S. Securities and Exchange Comissions (2016) said municipal bonds is are debt securities issued by states, cities, counties and other governmental entities to fund day-to-day obligations and to finance capital projects such as building schools, highways or sewer systems. In Indonesia, municipal bond is defined as regional loans which offered to the public through a public offering in the capital markets (Republic of Indonesia, 2008).

Purwoko (2005) distinguished municipal bond by their nature or behavior as well as the intended use of funds generated into: i) General Obligation Bond is a bond issued by the local government in order to obtain funds to finance the common areas, both for routine expenses as well as for projects of public facilities constructed by local governments, such as the construction of roads, bridges, and other facilities that are not generating revenue. Coupon and repayment of general obligation bond is fully borne by the budget.

ii) Special Revenue Bond is a bond issued specifically to finance construction projects that generate income, so that the coupon payments and redemption of the bonds will be paid from the income of the funded projects. Examples of revenue bonds are special highway construction, or the construction of tourist resorts. Both of these projects can generate revenue that can be used to pay the coupon and pay off the bonds.

iii) Limited Tax Bond is a bond that is used to build a particular project, such as shopping centers, where to pay coupons and principal of these bonds backed by taxes collected from the area of the shopping center.

iv) Double Barrel Bond is a bond to finance projects in large quantities. Because of the large amount of loans, repayment of these bonds need to be backed up by two or more layers. E.g. bonds issued to build the motorway. Besides using revenue from the motorway, the repayment of these bonds are also paid from the vehicle tax as second-tier backup. If the second tier backup not enough too, then could be backed up by third tier, and so on.

v) Incremental Tax Bond, the sale of these bonds are used to finance projects that do not generate revenue directly, but indirectly could provide additional revenue for local governments. This additional revenue is used to pay the coupon and principle. 


\section{Jurnal Keuangan dan Perbankan | KEUANGAN}

Vol. 20, No.3, September 2016: 369- 381

vi) Special Assessment Bond is used to finance the infrastructure that was built to be enjoyed by some community members, for example, building a network of gas to urban communities. The beneficiaries of this project is only the urban resident, therefore they should be responsible for the coupon payments and bond redemptions.

vii) Private Activity Bond, bonds guaranteed by the local government that aims not for profit. For example, bonds issued for the construction of hospitals or schools.

In case of Indonesia, municipal bonds are issued to finance a public sector investment activities that will generate revenue and provide benefits to the community although it is not necessarily full cost recover. Furthermore, the municipal bonds must not intended to cover cash shortfalls of local government.

\section{The Role of Municipal Bonds to Finance Regional Infrastructure}

The use of municipal bonds as a source of financing regional infrastructure development has been carried out in a number of countries. Including the United States which started in 1812 for the construction of the canal in the New York City (Fahim, 2012). Until now the United States is the most advanced in use of municipal bonds for infrastructure development (Platz, 2009). Then Europe is also well advanced with its municipal bond. From 1990 to 2007, the total value of municipal bonds issued by European countries increased from $\$ 118$ billion to $\$ 333$ billion. India began using municipal bond in the 1990s starting with the area of Ahmedabad, Bangalore, Hyderabad, Nashik, Nagpur, Ludhiana, Madurai, and Indore for the construction of several infrastructure projects (Chattopadhyay, 2006), although the development of municipal bond in India requires a long time.
The use of municipal bonds is quite successful in many countries, especially in America and Europe. By contrast, in Indonesia, the use of municipal bond to finance infrastructure development has not been done. Though municipal bond is one of alternative to finance infrastructure which more promising than just rely on government budget. In addition, municipal bonds also encouraged the local government to immediately implement the principles of good governance such as transparency and responsibility in the financial management area (Simatupang, 2012). Based on the SWOT analysis, the municipal bond issuance in Indonesia also deserve to be as one of source for infrastructure financing compare to others (Okta \& Kaluge, 2011). The advantages of municipal bonds are attract owners of the funds to invest, capable of providing large amounts of funds, have a low risk on changes in exchange rates, and have low risk on changes in government policy (Okta \& Kaluge, 2011; Simatupang, 2012).

\section{METHODOLOGY}

In order to analyze the possibility of issuance municipal bond to finance Jakarta MRT, this study used three perspectives including financial aspect, legal aspect, and DKI Jakarta financial capacity aspect. The analysis of the financial aspects were calculated using DCF, NPV and IRR based on financial model resulted from Special Assistance for Project Implementation (SAPI) for Jakarta Mass Rapid Transit System Project Study-2007 (Damodaran, 2011).

The DCF are used to reflects the cash flow resulted from the project, that will be used as underlying of municipal bonds issuance. It will give the information related to project liquidity ratio (cash adequacy) to pay the coupon as well as bond principal. Moreover, the NPV is a parameter to give a signal for the bond issuance, in which positive figure meaning the project gives positive value to the project (bond holder). Furthermore, in or- 
der to benchmark the coupon of the bond, the IRR is used as it reflects the minimal return that investor willing to achieve. Furthermore, Monte Carlo Simulation using Crystal Ball is conducted to the DCF calculation to give statistical framework to the result of IRR and NPV. While the bond market acceptance is analyzed by comparing the IRR as the results of the financial analysis with the risk free-30 years governement bond yield so that make the bond interesting enough to attract the bond investor in the market.

The methodology used in the legal analysis is by match the facts with the existing regulation related to the issuance of municipal bonds. Based on the findings, it can be known whether municipal bonds may be issued by Jakarta Government or not. Furthermore, to analyze DKI Jakarta financial capacity aspect, the authors used DKI Jakarta Regional Budget 2012 (APBD DKI Jakarta 2012) and Budget Audit Report as released by Supreme Audit Board as the basis of analysis.

\section{DISCUSSION}

\section{Financial Analysis}

The financial analysis were conducted to examine the possibility of municipal bonds as an alternative to the existing foreign-tied lending facility scheme to finance Jakarta MRT. Based on the data from the SAPI study, the authors calculate NPV and IRR using the discounted cash flow. In the SAPI study, the project will be financed by JICA (Japan International Cooperation Agency) in which offers soft loan for build Jakarta MRT infrastructure with low interest $0.4 \%$ per annum and loan tenor for 40 years. However, in order to get this facility, the project should be fulfilling specific requirements i.e the national eligibility of prime project supplier should be Japanese compa- nies and should apply Japanese technology for at least $30 \%$ as well as the need of JICA approval relating to procurement process.

In order to mimic real picture of current financial situation as well as for benchmarking purpose related to the issuance municipal bond planning, this study was assumed the specific financial parameters such as tariff, inflation rate, and exchange rate were adjusted from the SAPI study assumption. To sum up, the basic financial assumptions were used in this study as follow:

- Project Cost: Rp 11.679 billion (as per SAPI study);

- Demand Passenger 280.000/ day (JBIC Saprof Study Team, 2005);

- Tariff: Rp 15.000 (Fahriyadi, 2013). The fare increases every 3 years;

- Interest rates: Existing Loan Scheme JICA with interest $0.4 \%$ p.a (adjusted to the Samurai Bond Yield);

- Inflation: $10.24 \%^{3}$ (average yoy inflation 2007 to 2013) and compounded yearly;

- Concessions operation period: 30 years;

- Train Operation Planning:

o Headway: 5.5 minutes;

o Scheduled speed and time (one way): 27 $\mathrm{km} / \mathrm{h}$ and 31 minutes;

o Operating distances: $13,725 \mathrm{~km}$;

o Operating hour: 05.00 - 22.00;

o Stopping time at station: 1 minutes;

o Passenger capacity of 1 car: 140;

o Congestion ration in peak hour: $180 \%$ * $140=252$;

o Passenger capacity of 6 car (1 set) in peak hour: 1512;

\footnotetext{
Inflation Rate 2007-2013, National Statistic Bureau.
} 


\section{Jurnal Keuangan dan Perbankan | KEUANGAN}

Vol. 20, No.3, September 2016: 369- 381

To calculate DCF, NPV and IRR, authors use three basic assumptions, namely Capital Expenditure; Revenue and Operation Expenditure; and Cost of Financing.

\section{a. Capital Expenditure Assumptions}

The Jakarta MRT is planned to be developed in eight years, consists of two phases which are Engineering Services Phase (feasibility study and

Table 2. Detail of Investment of MRT Project

(Rp billion)

\begin{tabular}{|c|c|c|c|c|c|c|c|c|c|}
\hline \multirow{2}{*}{ Investment Cash Flow (year) } & \multicolumn{3}{|c|}{ E/S PHASE } & \multicolumn{5}{|c|}{ CONSTRUCTION PHASE } & \multirow[t]{2}{*}{ TOTAL } \\
\hline & 1 & 2 & 3 & 4 & 5 & 6 & 7 & 8 & \\
\hline Track, civil and electric works & 0 & 0 & 0 & 211 & 395 & 1.110 & 1.009 & 302 & 3.026 \\
\hline Elevated Guide way & 0 & 0 & 0 & 82 & 163 & 326 & 245 & 0 & 816 \\
\hline $\begin{array}{l}\text { Underground Guide way } \\
\text { (Shield Machine Use) }\end{array}$ & 0 & 0 & 0 & 86 & 148 & 311 & 233 & 0 & 777 \\
\hline track works & 0 & 0 & 0 & 44 & 84 & 170 & 127 & 0 & 425 \\
\hline $\begin{array}{l}\text { Power supply \& distribution } \\
\text { system }\end{array}$ & 0 & 0 & 0 & 0 & 0 & 83 & 111 & 83 & 278 \\
\hline $\begin{array}{l}\text { Signaling \& train control } \\
\text { system }\end{array}$ & 0 & 0 & 0 & 0 & 0 & 96 & 129 & 96 & 321 \\
\hline Telecommunication system & 0 & 0 & 0 & 0 & 0 & 36 & 47 & 36 & 119 \\
\hline SCADA system & 0 & 0 & 0 & 0 & 0 & 34 & 45 & 34 & 113 \\
\hline System integration & 0 & 0 & 0 & 0 & 0 & 25 & 33 & 25 & 83 \\
\hline Environmental control system & 0 & 0 & 0 & 0 & 0 & 28 & 38 & 28 & 95 \\
\hline Station works & 0 & 0 & 0 & 195 & 350 & 842 & 699 & 115 & 2.201 \\
\hline Elevated Station & 0 & 0 & 0 & 50 & 99 & 199 & 149 & 0 & 497 \\
\hline Underground Station & 0 & 0 & 0 & 145 & 251 & 528 & 396 & 0 & 1.320 \\
\hline station facilities & 0 & 0 & 0 & 0 & 0 & 115 & 154 & 115 & 384 \\
\hline $\begin{array}{l}\text { Lebak Bulus Depot \& connecting } \\
\text { guide way }\end{array}$ & 0 & 0 & 0 & 70 & 140 & 372 & 332 & 91 & 1.005 \\
\hline Rolling stock & 0 & 0 & 0 & 0 & 171 & 285 & 285 & 387 & 1.127 \\
\hline $\begin{array}{l}\text { Traffic management and utilities } \\
\text { diversion }\end{array}$ & 0 & 0 & 0 & 26 & 50 & 102 & 76 & 0 & 254 \\
\hline $\begin{array}{l}\text { Price escalation during } \\
\text { construction period }\end{array}$ & 0 & 0 & 0 & 43 & 118 & 343 & 353 & 142 & 1.000 \\
\hline Physical contingency & 0 & 0 & 0 & 27 & 61 & 153 & 138 & 52 & 431 \\
\hline Land acquisition and clearance & 219 & 0 & 0 & 0 & 0 & 0 & 0 & 0 & 219 \\
\hline Consulting services & 11 & 116 & 93 & 90 & 120 & 81 & 98 & 101 & 710 \\
\hline Administration cost & 1 & 9 & 7 & 61 & 82 & 193 & 175 & 41 & 570 \\
\hline Tax and duty & 1 & 12 & 9 & 76 & 163 & 386 & 350 & 139 & 1.137 \\
\hline Total Investment (E) & 232 & 136 & 110 & 799 & 1.650 & 3.865 & 3.514 & 1.373 & 11.679 \\
\hline $\begin{array}{l}\text { Total Investment adjusted } \\
\text { inflation (E') }\end{array}$ & 256 & 150 & 121 & 881 & 1.819 & 4.261 & 3.874 & 1.513 & 12.875 \\
\hline
\end{tabular}


preparation phase including land acquisition) and Construction Phase. In the first phase, the feasibility study are conducted comprehensively follows by procuring dan resettling the land in which take three years. The remaining five years in the second phase, mostly spent for MRT construction and civil works, including track, civil, and electric works building, station works, and also depos and connecting way works.

Based on per SAPI Study, total project cost is $\mathrm{Rp} 11.679$ billion, including development of trackway; stations and depos; electronic and signaling system; rolling stocks (cars); and traffic management utilities and diversion during the construction period. These project amount then adjusted with the inflation rate during 2007 to 2013 $(10.24 \%)$ to get the 2014 price which is Rp 12.875 billion. The 2014 price then will be used for further financial analysis.

\section{b. Revenue and Operation Expenditure Assump- tions}

After the completion of construction for five years, then Jakarta MRT assumes to be operated until the end of concession period of 30 years from the commercial operating date. Revenue is assumed to be collected from passengers tariff as a farebox revenue and other sources as non farebox revenue, including retail business development, advertising, telecommunication, and property development business.

Farebox Revenue is main revenue contribution for Jakarta MRT in which tariff is set equal to Rp15.000 as a base case, while the pessimistic and optimistic tariff is Rp13.000 and Rp17.000 respectively. Furthermore, the demand train passenger is forecasted 280.000 per day, while the optimistic case predicted the number $15 \%$ higher, and the pessimistic case predicted $20 \%$ lower. This passengers target will be reached with the specific conditions that are mostly under controlled by Provincial Government of DKI Jakarta i.e applying feeder transportation system, building park and ride facilities, applying mode of transport integration, and ERP (electronic road pricing). In addition, revenue also sourced from Non Farebox Revenue which to be assumed $10 \%$ of Farebox Revenue (MTR Hongkong, 2014).

On the cost side, the operation expenditure consists of three direct costs namely operation, energy, and maintenance costs, while depreciation of infrastructure and rolling stock will be treated as indirect cost. The biggest part expenditure is operation and maintenance $(57.9 \%$ of the total cost).

\section{c. Description Borrowing Costs (Cost of Financing)}

Based on the data of the financial model, to build Mass Rapid Transit (MRT) takes a total project cost of Rp 11.679 billion. Under the existing loan scheme, the project using funds mostly derived from the Japanese foreign loan (JICA) to finance the construction. In addition, small portion of fund should be allocated by Provincial Government DKI Jakarta to procure the land, pay tax and duty.

In this study, as the project will be bid out in the full competitive market and municipal bond will be issued in IDR (Indonesian Rupiah) denomination, the rate JPY loan needs to be adjusted. In order to doing this, the paper used Indonesian Samurai Bond Yield as the figure appropriately bridges the perspective of Indonesian and Japanese Financial Market.

\section{d. Financial Analysis and Market Acceptance}

Analysis of the financial aspects were calculated using DCF method to calculate NPV and IRR. As it can be seen in the Graphic 1, the negative cashflows occured during the preparation and construction phase, which reached the top at six year (Rp 3.561 billion), and accumulative amount Rp 12.875 billion (adjusted inflation). Furthermore, 


\section{Jurnal Keuangan dan Perbankan | KEUANGAN}

Vol. 20, No.3, September 2016: 369- 381

starting from commercial operation date, cash flow began positive as the project start to operate and receive revenue. The trend of the cash flow is increasing during the Operational Phase and attain break even point in year 24th or 16 years after the project is commercialized. It means that the investment cost is fully recovered by MRT revenue after 16 years of operation.

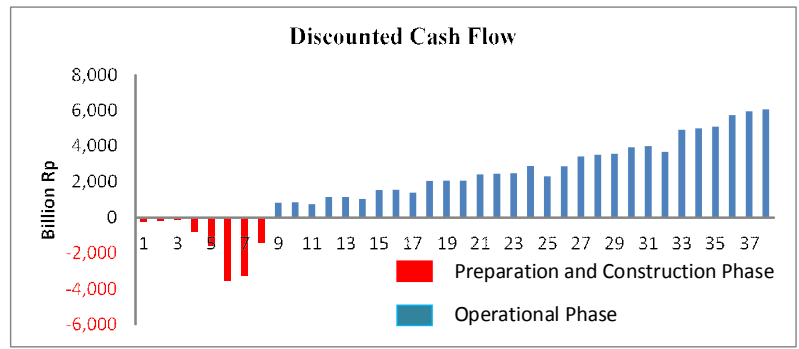

Graphic 1. Discounted Cash Flow

Based on the existing project cost structure (inflation adjusted) and existing financing scheme as in the SAPI study, the financial feasibility considerably strong results IRR $11.74 \%$ and NPV Rp53,155.74 billion during the 30 years operation period.

Project

\begin{tabular}{|c|c|}
\multicolumn{1}{c}{ IRR } & NPV \\
\hline $11.74 \%$ & Rp53,155.74 billion \\
\hline
\end{tabular}

As stated before, IRR number is the same meaning with bond yield (Sigman, 2005). This means that the IRR $11.74 \%$ of exisiting scheme should be at least the same with the risk free-30 years governement bond yield to make the bond interesting enough to attract investors in the market.

To strengthen the analysis, author also calculate IRR using Monte Carlo analysis (Graphic 2 and 3). The demand passengers and tariff is defining as the independent variable, in which the tariff is set equal to Rp15.000 as a base case, while the pessimistic and optimistic tariff is Rp13.000 and Rp17.000 respectively. Furthermore, the demand train passenger is forecasted 280.000 per day, while the optimistic case predicted the number 15\% higher, and the pessimistic case predicted 20\% lower. The Crystal Ball simulation results the certainty range of IRR is from $9.46 \%$ to $13.43 \%$ with certainty level 95\%, while the IRR more sensitive on the demand passengers $(65.2 \%)$ rather than the changing of tariff $(34.8 \%)$.

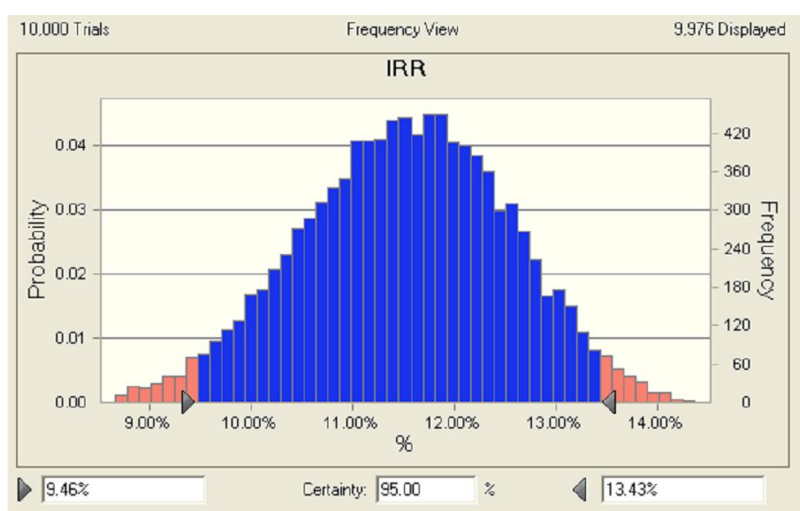

Graphic 2. Predicted IRR

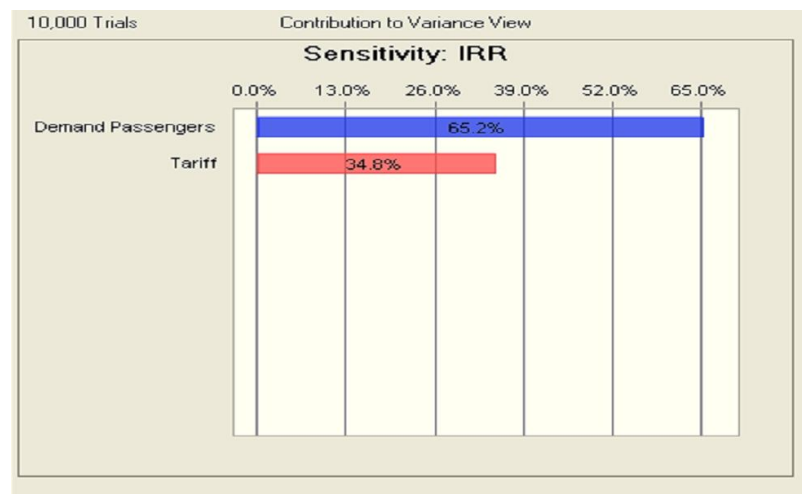

Graphic 3. Sensitivity IRR

On the other hand, the yield of 30 years government bond indicates that the investor required return from investing in government bond range from $6.37 \%$ to $9.68 \%$ during the last 2 years (Graphic 4) and the coupon of 30 years government bond series itself range from $7,875 \%$ to $9 \%$ (Table 3). 


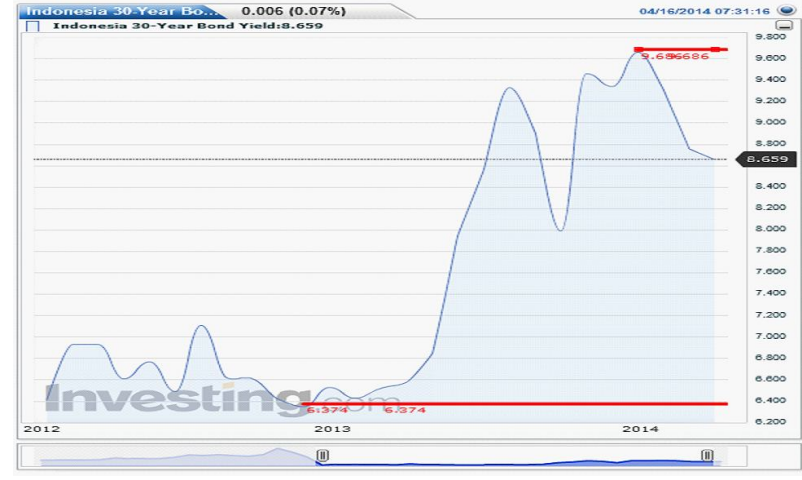

Graphic 4. Investor Required Return of Indonesia 30-Years Bond

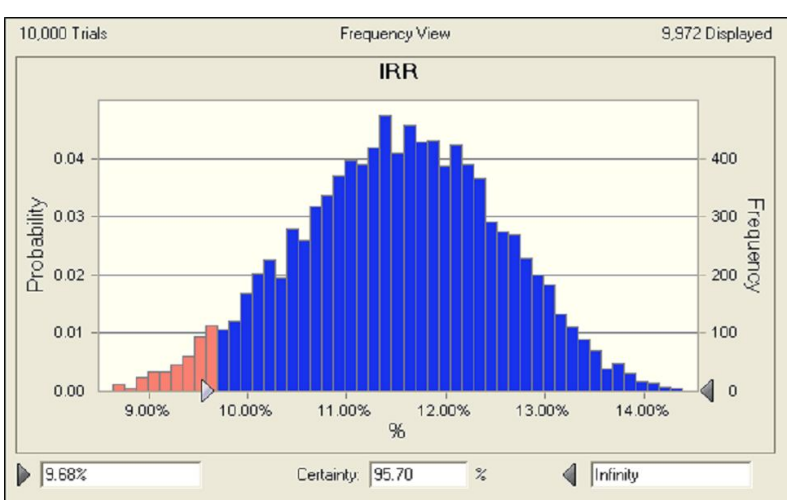

Graphic 5. Certainty Level of IRR Project

Table 3. Coupon of 30 years government bond

\begin{tabular}{ccccccc}
\hline \multirow{2}{*}{$\begin{array}{c}\text { TTM } \\
\text { Years }\end{array}$} & Series & \multicolumn{2}{c}{ Today } & \multicolumn{2}{c}{ Yesterday } & Coupon (\%) \\
\cline { 3 - 6 } & & Yield (\%) & Price (\%) & Yield (\%) & Price (\%) & \\
\hline 5.00 & FR0069 & 7.5039 & 101.5239 & 7.5788 & 101.2140 & 7.8750 \\
9.92 & FR0070 & 7.8171 & 103.7895 & 7.8217 & 103.7579 & 8.3750 \\
14.93 & FR0071 & 8.2088 & 106.7228 & 8.1895 & 106.8963 & 9.0000 \\
19.93 & FR0068 & 8.3910 & 99.8344 & 8.3978 & 99.7700 & 8.3750 \\
\hline
\end{tabular}

Source: investing.com, accessed on April 16, 2014.

It can be seen from the Graphic 5, with assuming the bond market perceived rate of return reach the top at $9.68 \%$, the certainty level of the IRR project will exceed the bond return is $95.70 \%$. This figure will give strong confidence to the market to buy the bond.

\section{Legal Aspects Analysis}

There are several regulations that has been established to regulate the issuance of municipal bond in Indonesia, which are Law 3/2004 regarding Fiscal Balance between Central and Regional Government; Government Regulation 30/2011 regarding Regional Government Loan; Minister of Finance Regulation No. 111/PMK.07/ 2012 regarding Procedures for Issuance of Municipal Bonds and Accountability; Minister of Finance Regulation No. 47/PMK.07/2011 regarding Procedures for Settlement of Delinquent Local Government Loans to the Central Government Through Intercep of DAU and/or DBH; Minister of Finance Regulation No. 54/PMK.07/2014 regarding Regarding Fiscal Capacity Map and Minister of Finance Regulation No. 125/PMK.07/2013 regarding Maximum Limit Budget Deficit Regional and Local Borrowing Cumulative Maximum Limit for Fiscal Year 2014.

Articles 54, 55 and 57-62 Law 3/2004 stipulates that municipal bond regarded as regional loan, so that, regional government can issue the bond by fulfilling the specific requirements and conditions as regulated. Moreover, Government Regulation 30/2011 regarding Regional Government Loan as derived regulation of Law 3/2004 clearly regulates the requirements and conditions that should be fulfilled by regional government in order to issue municipal bond as follow, 


\section{Jurnal Keuangan dan Perbankan | KEUANGAN}

Vol. 20, No.3, September 2016: 369- 381

The number of remaining regional loans plus loan amount to be withdrawn (as planned) does not exceed $75 \%$ of the total regional budget (APBD) in the previous year,

- Meet the criteria of financial capacity to repay loan (Debt Service Coverage Ratio) as regulated by the Central Government (at least 2.5),

- Has no delinquent loans to the Central Government,

- Regional/Local Parliament Approval

- Municipal bond is issued to finance the userpay project.

- Issuing only in domestic capital market and denominate in Rupiah.

- Municipal Bonds are not guaranteed by the Central Government.

- Audit of Regional Government Financial Reportreceived opinion Fair With Exceptions (WDP) or Fair Without Exception (WTP) from Supreme Audit Board (Badan Pemeriksa Keuangan).

Furthermore, the Minister of Finance Regulation No. 111/PMK.07/2012 regarding Procedures for Issuance of Municipal Bonds and Accountability stipulates detail mechanism to issue municipal bond including issuance planning, submission of proposal and approval mechanism, accountability mechanism, and monitoring evaluation mechanism. In addition, Ministry of Finance also establish some regulation regarding regional public finance to support the issuance of municipal bond such as Minister of Finance Regulation No. 47/
PMK.07/2011 as a legal basis to regulate the sanction to local government who mismanage the municipal bond, Minister of Finance Regulation No. 125/PMK.07/2013 as well as Minister of Finance Regulation No. 54/PMK.07/2014 to regulate the fiscal capacity of regional government as a basis to issue municipal bond.

Based on the facts, DKI Jakarta Government can fulfill all the requirements and conditions to issue municipal bonds. DKI has fulfilled the requirements of the number of remaining regional loans plus loan amount to be withdrawn. It is proved by the remaining DKI loans is $\mathrm{Rp}$ 903.875.313.321 (short term loan 891.621.380.088 and long term loan 12.253 .933 .233 ) or only $2.55 \%$ of the budget, far below the requirement of $75 \%$ of the budget. In addition, the debt service coverage ratio is $3472 x$, meaning that the budget surplus is 3472 times of the debt and principal expenditure, far above the requirement of only $2.5 x$.

Other parameter that shows the fulfillment of the municipal bonds regulation is DKI Jakarta Budget Audit Report as released by Supreme Audit Board. Audit reports for 5 years from 20082012 showed improvement of financial reporting, in which in 2011, for the first time, DKI Jakarta obtains an unqualified opinion with explanatory paragraph after previously always obtains qualified opinion and it is continued in the year 2012. The quality of financial reporting is one of important requirements for regional government to issue municipal bonds, and DKI Jakarta has fulfilled this requirement.

The municipal bond for MRT Project is also fulfilled the requirement of used to finance the user-

Table 4. Opinion of DKI Jakarta Budget Audit Report

\begin{tabular}{ccccc}
\hline $\mathbf{2 0 0 8}$ & $\mathbf{2 0 0 9}$ & $\mathbf{2 0 1 0}$ & $\mathbf{2 0 1 1}$ & $\mathbf{2 0 1 2}$ \\
\hline Opinion & Opinion & Opinion & Opinion & Opinion \\
Qualified & Qualified & Qualified & $\begin{array}{c}\text { Unqualified with } \\
\text { explanatory }\end{array}$ & $\begin{array}{c}\text { Unqualified with } \\
\text { explanatory }\end{array}$ \\
\hline Source: various source & & &
\end{tabular}



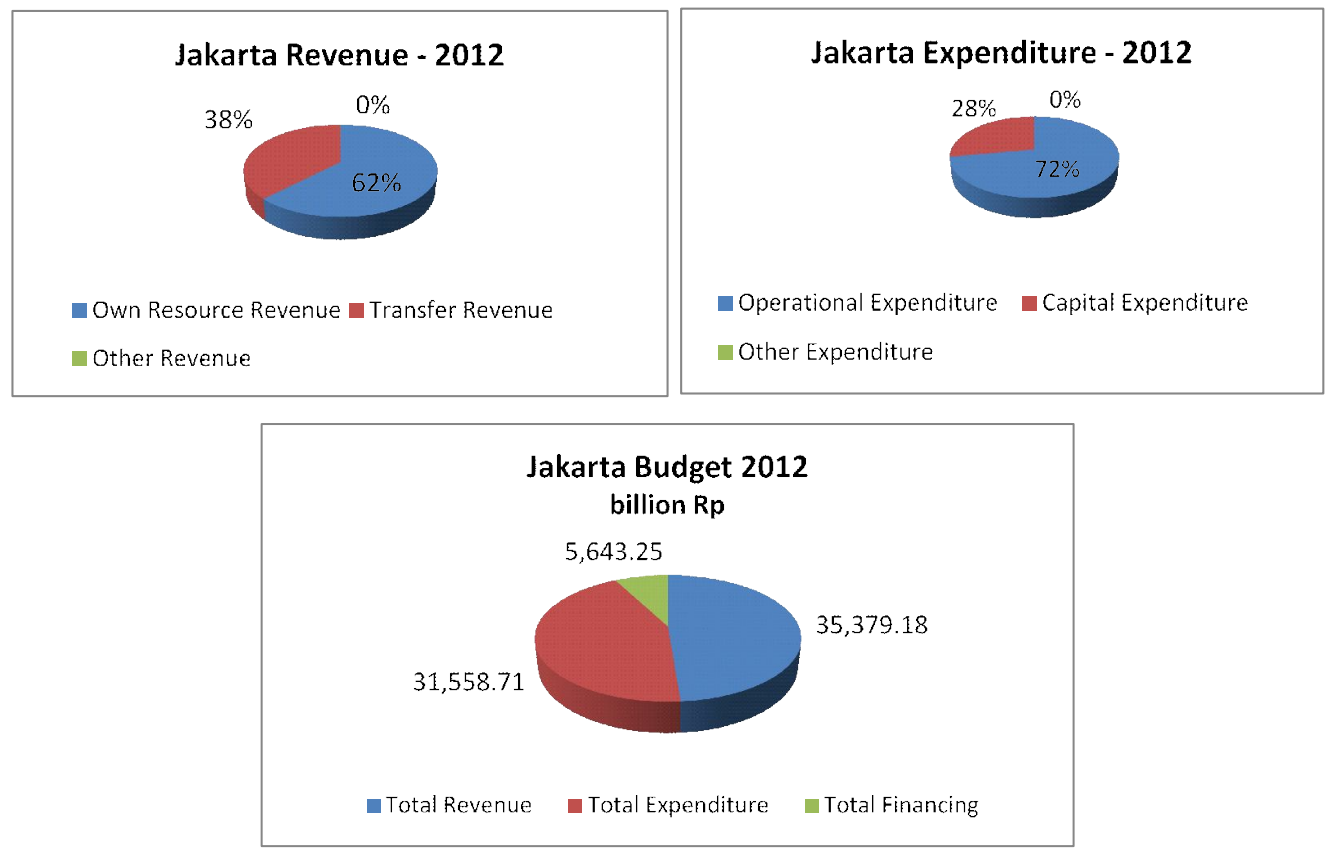

Graphic 6. Fiscal Capacity of DKI Jakarta Regional Budget 2012 Source: DKI Jakarta Regional Budget 2012

pay project and finally others requirement are only administrative requirement which definitely can be fulfilled by the DKI Jakarta Government.

\section{DKI Jakarta Financial Capacity as Underlying Municipal Bond}

In order to give financial capacity of DKI Jakarta Government as reflected in the Regional Budget, this study used the DKI Jakarta Regional Budget 2012 Audited (APBD DKI Jakarta 2012) to be analysed. The fiscal capacity is described in Graphic 6.

DKI Jakarta Budget 2012 revenue mostly source from own-source of revenue (PAD/ Pendapatan Asli Daerah) amount $62.3 \%$. In addition, the proportion of Fiscal Balance Fund from Central Government is $37.69 \%$, while other revenue count $0.01 \%$. Interestingly, the proportion of Fiscal Balance Fund is decreasing over time, mean- ing that the fiscal capacity of DKI Jakarta based on their own resource of fund getting stronger.

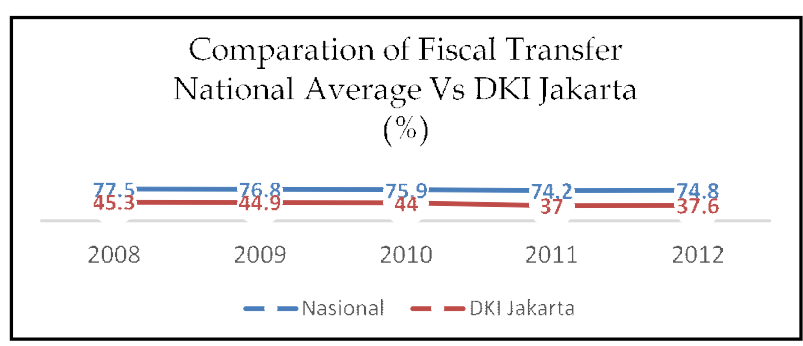

Graphic 7. Comparation of Fiscal Transfer Source: DKI Jakarta Regional Budget 2012, calculated

Furthermore, comparing the DKI Jakarta fiscal balance fund with the fiscal balance fund in national level (on average), it can be seen that the DKI Jakarta fiscal balance fund proportions are below the national figures (Graphic 7). In addition, the DKI Jakarta balance fund proportion also decreasing during the period of 2008-2012. It means that DKI Jakarta is financially independent 


\section{Jurnal Keuangan dan Perbankan | KEUANGAN}

Vol. 20, No.3, September 2016: 369- 381

from central government, as the balance funds getting lower over time.

The strength of the financial capacity is also acknowledged by international credit rating agency. In 2012, DKI Jakarta Government has achieved $\mathrm{BB}+$ and $\mathrm{AA}+$ from Standard and Poor's (S\&P) and Pefindo (Pemeringkat Efek Indonesia) respectively (Sindo, 2012). The ratings confirmed that DKI Jakarta is categorized as investment grade entity, meaning that The Government has adequate capacity to meet its financial commitments. However, adverse economic conditions or changing circumstances are more likely to lead to a weakened capacity of the obligor to meet its financial commitments.

\section{RESULT}

The possibility to use municipal bond to finance the urban infrastructure MRT Jakarta is so imminent. This study explores and reviews it based on three perspectives. Firstly, from the financial aspect, interpreting the IRR simulation result and the Government bond yield, it seems that the bonds with the underlying Jakarta MRT project will be easily accepted by the bond market, as the return offered by the project is above bond market perceived rate of return. Secondly, based on the legal perspective, the Provincial Government of DKI also eligible to issue Municipal Bond, as it has fulfilled all of the conditios and requirements as stipulated in various regulations. Lastly, it also backed up with its strength of the financial capacity, in which DKI has strong local revenue cash stream (Pendapatan Asli Daerah) and also acknowledged by International Credit Rating Agency.

\section{CONCLUSION}

The development of Jakarta MRT project is very urgent thing to do, not only for the Jakarta MRT project phase I, but also for phase II and so on. Jakarta MRT project phase I has been started by using Japanese loans as source of financing. Other financing alternatives can be done in phase II or later stages, and one of the alternatives is using municipal bonds. Our analysis by using financial analysis, legal analysis, and financial capacity of DKI Jakarta analysis with data and case study on Jakarta MRT project phase I said that it is feasible to use municipal bonds to finance the project.

\section{SUGGESTION}

The government of DKI Jakarta can propose the issuing of municipal bond to finance the infrastructure development, including MRT phase II and other transportation projects. In the wider perspective, this analysis model can also be applied to other regions who want to issue municipal bond in order to finance their infrastructure.

\section{REFERENCES}

BPS Jakarta. (2014). Data Kendaraan DKI. Retrieved March 18, 2015, from http://jakarta.bps.go.id/ linkTabelStatis/view/id/26

Chattopadhyay, S. (2006). Municipal Bond Urban for Financing Market Infrastructure. Economic and Political Weekly, 41(26), 2787-2791.

Damodaran, A. (2011). The Little Book of Valuation. New Jersey: John Wiley \& Sons.

Fahim, M. (2012). Municipal bonds have been issued by US local government since 1812. Retrieved March 25, 2015, from http://www.citymayors.com/finance/bonds.html

Fahriyadi. (2013). Tarif MRT Rp 15.000 per penumpang. Retrieved February 20, 2015, from http:// nasional.kontan.co.id/news/tarif-mrt-rp-15.000per-penumpang

Gardner, D., \&Wright, J. (2011). Project Finance. Retrieved March 15, 2015, from http://www.hsbcnet.com/ $\mathrm{gbm} /$ attachments/products-services/financing/ project-finance.pdf 
JBIC Saprof Study Team. (2005). Special assistance for project formation (SAPROF) for Jakarta Mass Rapid Transit (MRT) System Final report Special assistance for project formation (SAPROF) for Jakarta Mass Rapid Transit (MRT) System.

Koalisi TDM. (n.d.). Electronic Road Pricing. Jakarta. Retrieved from http://www.kpbb.org/news/tdmerp-factsheet-280111-screen.pdf

O'Hara, N. (2012). The Fundamentals of Municipal Bonds (Sixth Edit). John Wiley \& Sons.

Okta, D., \& Kaluge, D. (2011). Analisis Peluang Penerbitan Obligasi Daerah Sebagai Alternatif Pembiayaan Infrastruktur Daerah. Journal of Indonesian Applied Economics, 5(2), 157-171.

Perdana, M. A. (2013). Macet Terus, Jakarta rugi 65 triliun per Tahun. Retrieved February 10, 2015, from http:/ / metro.tempo.co/read/news/2013/03/ 24/214468984/macet-terus-jakarta-rugi-rp-65triliun-per-tahun

Platz, D. (2009). Infrastructure finance in developing countries - the potential of sub-sovereign bonds. DESA Working Paper. Retrieved from http:// www.un.org/esa / desa / papers / 2009/ wp76_2009.pdf

Purwoko. (2005). Analisis Peluang Penerbitan Obligasi Daerah Sebagai Alternatif Pembiayaan Infrastruktur Daerah. Jurnal Ekonomi Dan Keuangan.
Republic of Indonesia. (2008). Government Regulation No 54 year 2005 about Regional Loans.

Sheikh, S., \& Asher, M. G. (2012). A Case for Developing the Municipal Bond Market in India. ASCI Journal of Management, 42(1), 1-19.

Sigman, K. (2005). Internal rate of return, bonds, yields. Retrieved January 20, 2015, from http:// www.columbia.edu/ ks20/FE-Notes/4700-07Notes-bonds.pdf

Simatupang, M. (2012). Obligasi Pemerintah (Government Bond) Vs Obligasi Daerah (Municipal Bond). Retrieved January 20, 2015, from http:// www.bppk.kemenkeu.go.id/webku/images/ obligasi pemerintah vs obligasi daerah.pdf

Sindo. (2012). Kinerja Pemprov DKI raih peringkat AA. Retrieved February 15, 2015, from http:// news.okezone.com/read/2012/05/30/437/ 638013/kinerja-pemprov-dki-raih-peringkat-aa

U.S. Securities and Exchange Comissions. (2016). Municipal bonds. Retrieved March 5, 2016, from https:// www.investor.gov/additional-resources/news-alerts/alerts-bulletins/municipalbonds 